\title{
Federal Democracy Nepal: An Assessment of Two Years Democratic Practices
}

\author{
Associate Professor, Than Bahadur Chetri \\ Department of Political Science, Tribhuvan University, Prithvi \\ Narayan Campus, Pokhara, Nepal
}

\begin{abstract}
Nepal is on the way of institutionalizing federal political system. New democracy faces a number of challenges in institutionalizing. This paper, aims to understand the state of democratic practices and prospects of democracy in Nepal. It adopts political system approach and takes political ideas, power sharing, resource distribution, social identities, political values as independent variables and stability of democracy as dependent variable. It argues the prospect of democracy is uncertain. Country lacks several preconditions which are necessary for the success of federal democracy. Federalism is difficult to flourish in poor economy based society, incompatible political values, weak institution and poor governance.
\end{abstract}

\section{Introduction}

Modern democracy is a constitutional democracy. The process of building constitutional democracy starts following the replacement of undemocratic regimes and promulgation of constitution. In terms of qualities, constitutional democracy can be divided into two: electoral/ minimal democracy and maximal democracy. Minimal democracy is a form of government having "meaningful and extensive competition among individuals and organized groups, political participation in the selection of leaders and policies and a level of civil political liberties" (Diamond, et al., 1999; ix) as its essential components. Maximal democracy, more than procedural conditions, is a set of constitutionally 
protected property rights, political rights, and civil rights, with no ethnic or racial cleavages. The new democracy can move in differing direction, it may be consolidated or it may go 'competitive authoritarian', 'electoral democracy' and full autocracy (Diamond, 1999), (Haerpfer, et.al, 2009).

Nepal adopted Federal Democratic Republican constitution (2015), after repeated failure of democratic practices, to build prosperous nation, by devolving governmental power on behalf of the people, exercise of power without absurd, providing representation and distributional justice, inclusive with better citizen rights and free from external threat to sovereignty and harmonious relation all religion and countries. The elected government formed after the elections of three tiers of government has completed two years term in power. So, the government too has got its own responsibility to consolidate federalism.

Considering the endurance, Welzel (2002) argues that the establishment of federal political institutions and inclusion of legal rights are never sufficient to consolidate democracy. Elite's commitments are essential (Higley and Gunther 1992), (B.C Smith, 2009) in enduring democracy. To Linz and Stepan, (1996) 'behavioral, attitudinal and constitutional dimensions' are important. In the words of Anderson (2008), 'federal culture' and 'federal politics' and 'federal techniques' are the pre-conditions for federalism. Other studies argue it is the "experience of transition itself, a country's economic system, its political culture and its constitutional arrangements"(Beetham, 2007; 157) makes democracy success. Democracyvalues system (Sodaro, 2001), rests on 'virtues' (Hood, 2014).Lately, a host of scholars have identified populists rule, be it a left or right, "to have a highly negative effect on political systems and leads to a significant risk of democratic erosion" (IFGC, 2018; 3). The populist politicians 
and parties are challenging "to both established and younger democracies" (IDEA, 2020) in recent years. The discussion shows that the institutionalization of democracy is influenced by the political values of the party leaders and their ideals of party. The varieties of democracies are the outcome of the nature of political parties. Thus, political values make effect in power sharing, resource distribution, collective identities.

According to David Easton, political system is that "system of interaction in any society through which binding allocations or authoritative allocations are made and implemented". Political system, 'sub-system of society operating within an environment', developed by David Easton in his two famous books, is a new approach to analyze the problem and explaining the problems, which are common to all political systems, from the same angle. The essential features of political system include: a set of interrelated and interdependent parts; perform multiple functions; universally accepted and unquestioningly authoritative; maintain law and order. Any political system has two components inputs and outputs. The inputs include demands (claims, desire, needs made by the general public, these claims arises from agitation, elections and appeals) and supports (towards the system by obedience of political values, it helps legitimacy of the government). The outputs are the 'allocation and distribution of values'. Every system has its boundary and environment that continuously interact with economic, sociocultural as well as international society. Feedback is about the performance of the system. The stability of political system depends on its capabilities.

Democracy is a set of interrelated and interdependent formal political institutions, actors and political process, establish for the betterment of society. It concerns to the needs and aspiration 
of the community. The formal structure determines the process of electing actors with roles and responsibility. Democracy as a system, it receives political inputs from the society to the formal institutions in the form of representative from different social groups into parties. The inputs of the political system are converted into political outputs, known as political decision or polices adopted by the elected representatives. It may be distributions, regulations, extraction and symbolic acts (Almond et al., 2011; 28-29). The actors and political institutions create, enforce and apply laws for the society. The feedback mechanism gives rise to fresh demands. The political system is surrounded by its environment and changes in its environment with new demands and support. The political system operates under the rules of game, needs, minimum support from the public. Thus, this approach helps to explain how national government or formal institution such as parliament, the executive and judiciary collectively make, implement, enforce public policy and distribute resources. Likewise, it helps to understand how citizens make their preferences to the system, respond to policies and so on.

This paper follows 'political system approach', a useful model developed by David Easton to choose issues and problems, and to analyze them in a proper viewpoint. It takes Actor's ideas as the input variable of the political system and power sharing, recourse distribution, political values and social identity as the output variables. The outputs are the policies and decisions of the government will transform into a new demands in a feedback as shown in the following Easton's model. 


\section{Table of Political System}

\section{Environment}

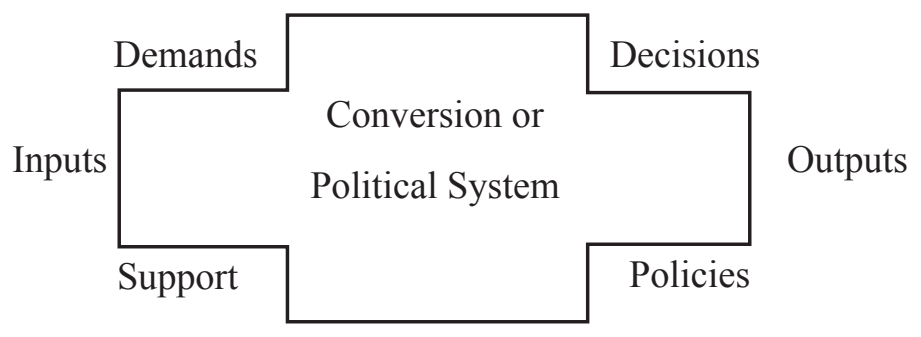

Internal and External

Feedback

\section{Environment}

Source: Modified Version of Easton Political System (1957; 383).

\section{Method of Data Collection}

This paper aims to understand the state of democratic practices under Republic Nepal. For this purpose, the information needed is collected from various secondary sources. The following table describes in detail the method of information collection.

\begin{tabular}{|l|l|l|l|}
\hline Variables & $\begin{array}{l}\text { Sub } \\
\text { variables }\end{array}$ & Question & $\begin{array}{l}\text { Information Collection } \\
\text { Methods }\end{array}$ \\
\hline $\begin{array}{l}\text { Input } \\
\text { Ideas }\end{array}$ & $\begin{array}{l}\text { a) Political } \\
\text { the world in which } \\
\text { they live? }\end{array}$ & $\begin{array}{l}\text { How the actors view } \\
\text { parties and behavioral practices } \\
\text { of army, bureaucrats and other } \\
\text { actors }\end{array}$ \\
\hline Output & $\begin{array}{l}\text { Sharing } \\
\text { Sower }\end{array}$ & $\begin{array}{l}\text { How power is } \\
\text { shared? }\end{array}$ & $\begin{array}{l}\text { Government's decision, INSEC } \\
\text { Report, World Report (2019) }\end{array}$ \\
\hline
\end{tabular}




\begin{tabular}{|l|l|l|l|}
\hline & b) Recourse & How, chronic is \\
Distribution & poverty, national \\
wealth distribution? & $\begin{array}{l}\text { Government of Nepal and } \\
\text { Ministry of Finance, Oxfam } \\
\text { and HAMI, ADB, Nepal } \\
\text { Economy Forum, USAID, } \\
\text { CIAA, Trading Economics. }\end{array}$ \\
\hline & $\begin{array}{l}\text { V) Political } \\
\text { Values }\end{array}$ & $\begin{array}{l}\text { What values do } \\
\text { political elites hold? }\end{array}$ & $\begin{array}{l}\text { Methods of political actions, } \\
\text { decisions of administrative and } \\
\text { political leaders. }\end{array}$ \\
\hline & $\begin{array}{l}\text { Identity } \\
\text { d) Collective }\end{array}$ & $\begin{array}{l}\text { How other identities } \\
\text { are challenging } \\
\text { collective identity? }\end{array}$ & $\begin{array}{l}\text { Nepal - WWL 2020 Country } \\
\text { Dossier. }\end{array}$ \\
\hline e) External & $\begin{array}{l}\text { What is the state of } \\
\text { Eilateral relations? }\end{array}$ & $\begin{array}{l}\text { Printed and online materials on } \\
\text { diplomatic controversies }\end{array}$ \\
\hline Published & materials & $\begin{array}{l}\text { Concept, literature } \\
\text { review and published } \\
\text { cases on study topic }\end{array}$ & $\begin{array}{l}\text { Government and international } \\
\text { publications, constitution, } \\
\text { journals, materials available at } \\
\text { internet and published books. }\end{array}$ \\
\hline
\end{tabular}

Source: Self

\section{Assessment of Two Years Democratic Practices}

1. Input: The input denotes 'who govern us'. In a representative system election is the method of acquiring the mandate to rule by the representatives of the political parties. The elections of all the three layers of government was held in 2017, for the first time after the promulgation of new federal constitution in Nepal. It gave Nepal Communist Party a comfortable majority in the federal Parliament with the support of the Federal Socialist Party. Out of seven provinces, it formed government in six provinces. Nepali Congress, Rastriya Janta Party Nepal (RJPN), Federalist Socialist Forum, Nepal (FSFN) got second, third and fourth position respectively. The other parties; Rastriya Prajantantra party, (RJP), Naya Shakti Party, Nepal (NSP, N), Rastriya 
Janamorcha (RJ), Nepal Workers Peasant Party (NWPP) and Independent have got one seat each. The following section discusses how the actors view the world in which they live.

\section{a) Ideas}

Democracy needs democratic ideas and democratic practices to govern the nation. The present government was formed from the communist Party of Nepal that received the majority of seats in the parliament. Prior to the election held for the parliament, it heed an alliance with its left forces like the maoist. As a result it won the majority of seats in parliament and formed the government. The communist party so united believes in 'Marxist and Leninist', 'secularism and federalism' with 'people's multiparty democracy', but its 'ultimate goal is communism'. At present, it is pursuing both the features of communis in and liberal democracy. Because of this dual policy of following the features of communism and democracy, it necessarily contradicts to the basic feature of democracy. Both academicians and the international community are raising doubt about the prospect of democracy under the strong communist led government. To get continue support from the people and the international agencies, it has adopted a soft policy towards major international powerbased countries. Currently, many leaders prefer directly elected executive, citing reducing electoral expenses and reducing corruption, a route to electoral violence and autocracy.

The Nepali Congress (NC), the main opposition party, seems to have deviated from its ideals, is struggling with never ending group/s and factionalism with many divergent political ideals and power centers. The party is unable to play effective role of opposition party in the parliament in checking the nation from the rise of a 'new autocracy'. Rastriya Janta Party Nepal (RJPN) 'believes in identity, rights, respect, democratic 
socialism and regionalism'. The Samajwadi Party-Nepal (SPN) views democratic socialism, ethnic federalism with presidential system of government and a fully proportional electoral system, to cure all ills of the country. Rastriya Prajatantra Party (RPP, Nationalist) gives emphasis to have a 'Hindu state, democracy with monarchy', is using it as a bargaining tool to gain power.

The Nepal Army (NA), a nonprofit institution, is lobbying for amending its act to invest in profit making sectors. It possesses both gun and money and is above 'the corruption law'. Besides social service, N.A is, investing its welfare fund in profit making areas, lobbying for opening bank and investment in hydro. There is a tendency of picking up the judges on the basis of 'divide and share' among the political parties, without caring meritocracy. It has lost the concept of independent and impartial judiciary due to controversial in the appointment of the judges since many years. Nepalese bureaucracy is, facing scarcity of values, largely criticized for 'corrupt', 'out-dated' and 'non-performing institution'.

The anti-system actors includes Chand group, a splinter group of former Maoists party, challenging strong government, started violent activities to complete the previous Maoist war, in the name of the welfare of the people. The government has banned all its activities now. Mohan Baidhya, General Secretary of Nepal Communist Party (Revolutionary), wants to 'replace the regime' and advocates another struggle and seeks to tactical alliance with the Biplab's party. Former King too wants to return back in power. Practically speaking, Nepalese political parties, from the individual and institutional perspectives, are not gender and inclusive friendly and internally democratic.

2. Outputs: Governmental outputs are in the form of goods and services produced by different government agencies, reflection 
of self-governing, laws, decisions and policies according to the constitutional values. The following section deals with the performance of the government in different sectors.

\section{b) Power Sharing}

Federalism is for power and justice. The present government is not functioning according to these principles. The attitude and behavior of the federal leaders and the bureaucrats remains centralist. The Prime Minster brought major institutions under his office. Many controversial bills are introduced in the parliament, the University Bill, National Security Bill, National Human Rights Commission (NHRC), the Information Technology without the participation of stake holders. Following the wide criticism from different circles, the government withdrew 'Guthi Bill' and revived previously scraped mega projects without competitive bidding. Scholars opine the decision making process of the cabinet government closely resembles 'Bhardari Sabha' of the autocratic Rana regime. The standing committee of ruling party decided the name and capital of Province no 3 that contradicts with the constitutional provision. Even after spending two years, the provincial governments are showing incapable to pick up the names of provinces and capital. The main responsibility of federal government is to formulate and enact the laws, devolve the power to the lower level. The provincial governments have not been able to exercise the constitutional power, due to 'lack of rules and procedures'. Both provincial and local governments are running under the shadow of federal. They are facing the shortage of human resources, administrative structures as well as weak coordination between Federal and Provinces. Provinces are working as ceremonial status. The bureaucracy still remains centralized. Federal government recruited the civil servants of all the layers of governments, without participation and 
consultation of sub-state and local governments. It appointed and mobilized secondary school teachers by setting up separate units of the education ministry in the districts. The Province No 2 challenged in the court against the Federal government's decision of transferring Sagarmatha Forestry Development Project to the Forest Corporation. The CDO Offices are running as a parallel power center in district level with a right to mobilize the police security.

The constitution envisages several constitutional bodies. Prime Minister is the head of these bodies. But, these bodies are running without their head and office bearers. These bodies are unable to carry out needed decisions, to make plans and program lacks of human resources in them. Lots of people are deprived of education, employment and other facilities, due to delay in passing Nepal Citizenship Amendment Acts. Ganga Maya is still waiting the day of justice. Her teenage son was murdered by the rebellion on 6 June 2004. Neither the government nor Human Rights groups are interested in 'bringing the accused to the judicial process' (INSEC, 2020). She, now, wants the role of UN to ensure justice.

The government's role is futile in the protection of women and girls rights, especially the lower caste and indigenous communities. No efforts from the government's side to identify the accused persons on the rape and sexual violence cases during the insurgency period (INSEC, 2020; World Report 2019). Except legal and constitutional compulsion, women's representation in key decision-making bodies remains disappointing.

\section{c) Resources Distribution}

National wealth makes people proud of their country, brings stability and consolidation of democracy. It can be possible when national wealth is redistributed more or less equitably 
across the country. Hence, 'appropriate social and institutional mechanisms' are essential to ensure equitable distribution and strengthening democracy. Geographically, most of the region of the country is covered by high mountains and Himalayan regions. More than 6 million people are below the poverty level (GoN MoF, 2018) in Nepal. Out of seven, province no 2 and 6 are the poorest (Oxfam and HAMI, 2019). The revenue is inadequate to meet the development expenditure. Every year trade deficit is widening, the 'imports of oil, construction materials, machinery, automobiles, and electric appliances are soaring up', (The Trading Economics, 2019). The overall "inflation rate has reached at 6.9 in 2020 February" (The Trading Economics, 2020; 5). The country lacks adequate economic resources to invest in industry, private and foreign industries do not want to come due to varieties of reasons. At present, Nepal is exporting energetic youths to foreign countries for their livelihood. Many of them return in coffins. Remittance, the main source of foreign currency earning, is contributing a widening "gap between rich and poor" (Oxfam and HAMI, 2019). National economy system is concentrated in the hands of few elites. Varieties of 'Crony Capitalism' and corruption are the outcome of this situation. The industrial sector mainly involves in the processing of agriculture products. Market friendly economic policies and practices are lacking. The provinces and local governments are largely relying on revenue shared by the central government and poor systematic mechanism to collect tax (ADB, 2019). The country lack adequate economic resources to invest in industry, private and foreign industries do not want to come owing to corruption and other bureaucratic hurdles. Seeing no opportunities in the country energetic youths prefer to go to foreign countries for their livelihood. Many of them return in coffins. At the request of the government, multi-donors are helping the country in 
strengthening federalism including "fiscal decentralization and public financial management reforms" (ADB, 2019; 11).

Agriculture 'provides livelihoods for $68 \%$ of Nepal's population'. Now, its share in GDP shrinks down into '27.6 percent' (ILO/ USAID, 2019). Nepal once was a rice exporter country. At present, fertile lands of the country are covered by buildings and houses. Local production barely meets the demand of the people. The country heavily relies on imports of food grains, vegetables and fruits. The continued decline in agricultural production has depressed rural economies and increased widespread hunger and urban migration (USAID, 2019). In brief, dependency on imported food and fruit is ballooning.

Federalism is for minimizing for inequality and poverty. The national budget too aims in improving the living standard of the people with rapid economic development social justice and building foundation for socialism oriented (GoN/MoF, 2019). ADB's study shows that there is "poor links between budget and sectorial plans" (ADB, 2019; 38). The federal government still continues old habit distribution of national budget on the basis of political access and political influences by the ministries and the powerful leaders, without a feasibility study of the plans and programs. Recently, government started collecting infrastructure development tax from fuel without the ratification of parliament, 'manipulation of tax system'.

The government of Nepal launched Prime Minister Agriculture Modernization Project (PMAMP) to boost 'productivity and food self-sufficiency' with incentive to youths. Several studies show that PMAMP there has no change in their life style of the peasant before and after the program. In this connection, Bhairab Raj Kaini pointed out in an article, entitled "Why agriculture programs fail", the main reasons behind the failure 
of agricultural programs in Nepal links to 'poor evidence based analysis', 'unsupportive behavior and frequent transfer of bureaucrats' and 'appropriate organization to implement agriculture programs'. Nepal Economy Forum (2020; 22) reports, 'ambiguous law, poorly implemented strategies and federalism, governance barriers and declining traditional best practices', being a subsidiary program. Every year farmers face shortage of fertilizers, sugarcane producers are on the street in getting their due.

Likewise, the Prime Minister Employment Program (PMEP) (GoN/MoF, 2019; 8), a plan to mobilize jobless youths and discourage foreign employment, was implemented in all 753 local levels. The program was praiseworthy, but implemented without 'plan and monitoring and implementing agencies'. The local leaders twisted the income generating rules, others failed to implement, real people unable to take the benefits of the program, budget spend on allowance and salary instead of income generating skills.

The new constitution assigned fiscal authority to all the three tires of government, but it lacks "clarity on revenue and expenditure assignments among all layers of government (ADB, 2019), (Shrestha, 2018), 'skilled human resources' at provinces. The center government retains half of the total royalty generated by the local governments, while the rest are shared between province and local governments (GoN/MoF, 2018). The revenue generated by the provinces is not enough to meet the administrative expenses. Internal borrowing helps them meet expenditure needs. The delay in the formation of various political institutions such as Inter-State Council, Intergovernmental Fiscal and Natural Resources Commission, State-Local Governments Council and District Coordination 
Committees has been contributing to the conflict between three tiers of governments over resources and jurisdictional issues. Leaders of the province no 2 filed a case at Supreme Court against central government for transferring Sagarnath Forestry Development Project to the Forest Corporation. Similarly, there have been frequent clash of over jurisdiction between central and local government over jurisdiction.

The country has adequate rules and regulation and government is declaring its zero tolerance against unethical behaviors of bureaucrats and elites, but there is no sign in improvement in the good governance situation. The Italian contractor abandoned Melamchi water project, which was started 18 years ago, without completing its task, due to controversy over politicization and misuse. The unholy relationship of politicians, middlemen and bureaucrats has been contributing to institutional corruption at policy level and in infrastructural development project. According to Transparency International's Corruption index, Nepal is ranked '124th out of 180 countries' in in 2018'. A study conducted by the Commission for the Investigation of Abuse of Authority (CIAA) (2076) found that corruption at local level has increased after the election. National pride projects are running sub-standard work or delaying in completion. The singers and comedians are educating the people about the state of corruption in the country through satirical songs.

\section{d) Social Identity}

Constitution is about how to live together happily. It addresses diversity and makes pride of nation and collective identity. Federalism, republic system and secularism are the pillars of collective identity of Nepal, as per new constitution. These are now growing questions. Religiously, majority of the population are Hindu. They believe that some political leaders coming under 
the influence of donors ended the monarchy unconstitutionally and in a tricky way declared the country a secular state, now the issue of religion is emerging again. The pro Hindu party is pressuring to make the country a 'Hindu State'. The number of Christian populations and churches have drastically increased in Nepal, a home of "fastest-growing Christian populations in the world (Pattisson, 2018 cited in Nepal - WWL 2020 Country Dossier) after the political change. The donor countries want to see Christian population in governmental institutions. They are investing money in the name of strengthening democracy, empowerment and communication. The Christian community voices right to conversion and cow slaughtering to be made legal with several social rights (Nepal - WWL 2020 Country Dossier). Both of these are unlawful and challenge to the glorious civilization of Nepal. Government worked as co-organizer of Asia Pacific -Summit held in Kathmandu, that promotes Christianity. The Muslims too are persuading people to change from Hindu to Muslim in the Tarai regions. If anti secular grows stronger, chances of new tension are likely to grow in the future. The ethno leaders and populist leaders may try to radicalize religious nationalism to gain power, property and privileges.

K. C. Where, an eminent scholar of federalism, argues "desire to live under regional government and a capacity to work under the federal system" (cited in Erk and Anderson, 2009; 193) are essential conditions for success of dual government. People are now raising questions about viability of sub-governments. To them, provinces were demarcated at the whim and interest of the few leaders, without caring geographical and other capabilities. Taking the benefit of the gap of ideology in parties, some regionalist group is demanding re-demarcation provincial states and observing constitutional day as 'Black Day'. They are trying to dilute federalism. 


\section{e) Political Values}

Constitutional values are those values expressed in the preamble of the constitution for advancement of the political community and ensure a just and fair society. Political values, can be measured, are those "set of political actions, decisions and methods used by the administrative and political leaders" (Loek, 2007). The old political values, politics is for the welfare of the people changed into group profits, motives, due to development of network politics, created by powerful leaders. Dependencies of leaders have greatly increased on big corporation and financial aid institutions to political parties, consultants, advisor but less on ordinary people (Crouch, 2004). Party politics become meaningless, public policies are determined by 'economic actors and the political actors' (Crouch, 2004). Legislative bills are prepared by a handful people at central level. A hired lawyer prepared new laws at provinces and local levels. These are passed without consulting the stakeholders and civil society. It is curtailing political and social rights of the people including right to legitimacy to rule by the legislature of the three levels of government. The leaders are showing little interest in parliamentary debate and discussion. Powerful ministers and leaders are busy in searching projects for their cadres, whereas bureaucrats and the INGOS are in policy making. Defamed persons receive awards from the government.

Political leaders grossly misused the proportional electoral system. A controversial person, who has been accused of murder, became the Speaker of the House of Representatives (Nepal Economic Forum, 2020) in spite of protest from right activists and civil society. Gender and ethnic inclusion and representation justice become meaningless. The residential place of the President turns into party office. The sister organizations of the parties are running without office bearers for many years. Some 
parties are unable to hold their convention, owing to autocratic leadership and fraction of many power centers. The leaders neither listen to the voices of their cadres nor follows party statue. Parties are unable to hold to hold their convention. The constitution mandates a minimum of $33 \%$ of women in the party structure and governance that remains a distant dream. Even at provincial and local government levels, women's presentations are secondary. Thus, democratic institution and procedures are losing their influence. Politics is moving towards counter trends.

\section{f) External Environment}

A nation maintains different kinds of relationship with different countries and organizations to fulfill national interest through foreign policy. Nepal's foreign policy is guided by United Nation Charter and non-alignment policy as well as diplomatic code of conduct. The new government started with the slogan of "Amity with all, enmity with none," "a good friend of all', in foreign policy, to diversify economy. The government is showing unable to maintain balance to major countries. Several diplomatic controversies surfaced with India, USA and China due to diplomatic immaturity. It has weakened the state's policy making capability, coordination in foreign aid, and maintaining sovereignty. Frequent interventions of international actors in the internal matter, border encroachment by the neighboring country and non- acceptance of Eminent Persons Group Report are the outcome of weak diplomacy and absence of common consensus among the leaders of the parties on national interest. Economic diplomacy is the core foreign policy of Nepal. The ambassadors are not appointed on the basis of merit and competency.

\section{Discussion}

Constitution of Nepal aims for the transformation of society. 
This paper aimed to understand the state of democratic practices and its prospects for a democratic future. It argues that politics need democratic ideas and supply of democratic values by the actors of federal democracy. Erosion in the functions of the parties has contributed varieties of populist parties and network politics. Leaders become dependent on small elites or advisors and financial aid contributors. Their political values or behavior are contradictory to the constitutional values. More power, property and privileges are the prime interest of the rulers, instead of empowering citizens. Democratic norms, values and principles are in crisis. Federalism is for power and justice for grassroots people but it is personalized and centralized by the federal government. Constitutional organs lack necessary human resources and operating laws. Government shows no urgency to fill them. The provincial and local governments are unable to carry out their assigned functions. Party politics is becoming meaningless and people deprives of power. Gender and ethnic representation in various organs, except constitutional provisions, still remains incomplete. Government is committed to make a prosperous country. Country needs superior educational system, modern agriculture firms and energetic creative youths to convert goods and services. In reality, dependency on food and fruits has increased and trade deficit is swelling. Manipulation of tax, national budget, weak regulatory governance and nonindependent, poor service delivery and fiscal indiscipline at local levels has been contributing further inequality. Collective identity is in crisis due to poor economic development and absence of value change in society. Provincial states are created by the parties, lacks ownership.

Building democracy means change in actors and governmental structures as well as aspiration of people. Democracy always needs good leaders and virtues (Hood, 2004). The attitudes 
and behavior of the elites are contradictory to the principles of democracy. It carries dual ideology. Representational justice and inclusion and transitional justice still remains a slogan. The political values are incompatible with the constitutional values. No effective efforts has launched by the government in improving governance, controlling corruption. Weak institutions and poor implementation of policy has been contributing grand and petty corruption. Public views and access is lacking in legislation making process. Poor service delivery and no service delivery from the governmental agencies are not helping a sense of living under the state and realization of constitutional rights. It is further creating inequality. Bureaucrats are unable in upholding democratic values and ensuring citizens' rights. Federalism is difficult to flourish in poor economy based society. It needs groups of middle income people. In Nepalese context, state employees are more than the state requires. They are practicing informal rules. The research findings of Huntington (1991), Lipset (1959), Betham (1994) Anderson (2008) and Hood, (2004) are appropriate in the context of Nepal. Thus, the prospect of federal democracy in Nepal is uncertain.

\section{References}

Alond, Garbriel A. et al (2011). Comparative Politics Today: A World View. 9th ed., India, Pearson

Anderson, George (2008). Federalism: An Introduction. New York, Oxford University Press.

Asian Development Bank (2019). Governance and Institutional Risks and Challenges in Nepal. Philippines https://www. adb.org/sites/default/files/publication/543056/governanceinstitutional-risks-challenges-nepal.pdf. Retrieved on 2020/1/18.

Couch, Collin (2004). Post-Democracy. U.K, Polity Press.Eston 


\section{David (1957).}

David Beetham (2007). Conditions for Democratic Consolidation. In Review of African Political Economy. Pp. 157-172. https://www.tandfonline.com/doi/ abs/10.1080/03056249408704053. Retrieved on 2020/1/18.

Diamond, Larry, et. al (1999). Democracy in developing Countries: Latin America. $2^{\text {nd }}$ ed. London, Lynne Rienner.

Easton, D. (1957). An Approach to the Analysis of Political Systems. World Politics. 9(3), 383-400.

Erk, Jan and Anderson, Lawrence (2009). The Paradox of Federalism: Does Self-Rule Accommodate or Exacerbate Ethnic Divisions?, In Regional \& Federal Studies, 19:2, 191-202, https:// DOI: 10.1080/13597560902753388.

Government of Nepal Ministry of Finance (2019). Economic Survey 2017/18. https://mof.gov.np/uploads/document/file/ for\%20web_Economic\%20Survey\%202075\%20Full\%20 Final\%20for\%20WEB\%20_20180914091500.pdf.

Government of Nepal (2019). Budget Speech of Fiscal Year 2019/20. https://mof.gov.np/en/2019/06/19/news/ news/1754/.

Government of Nepal Ministry of Finance (2018). An Act Made to Intergovernmental Fiscal Arrangement. https://mof. gov.np/uploads/document/file/An\%20Act\%20Made $\% 20$ to $\% 20$ Intergovernmental $\% 20$ Fiscal $\% 20$ Arrangement $\% 20$ final\%2011-15_20180305120026.pdf.

Government of Nepal NPC/ OPHI (2018). Nepal's Multidimensional Poverty Index: Analysis Towards Action. https://www.npc.gov.np/images/category/Nepal_MPI.pdf.

Haerpfer, Christian W.; Bernhagen,Patrick; Inglehart, Ronald F and Welzel, Christian (2009). Democratization. New York. 
Oxford Press.

Halman, L. (2007). Political Values. In Edited by Russell J. Dalton and Hans Dieter Klingemann. The Oxford Handbook of Political Behavior, https:/DOI: 10.1093/ oxfordhb/9780199270125.003.0016.

Higley, J. and Gunther, R. (1992). Elites and Democratic Consolidation in Latin America and Southern Europe. Cambridge University Press.

Hood, S. J. (2004). Political Development and Democratic Theory: Rethinking Comparative Politics. New Delhi. Prentice Hall of India.

IDEA (2020). Global State of Democracy in Focus. https:// www.idea.int/sites/default/files/publications/populistgovernment-and-democracy-impact-assessement-usinggsod-indices.pdf. Retrieved on 2020/4/ 13.

Informal Sector Service (2020). Nepal Human Rights Yearbook: Expectation: Towards Political Stability. https://www.insec. org.np/wp-content/uploads/2018/02/RS54479_RS54479 nepal-Human-Rights-yearbook-2018-eng.pdf.

Linz, J. J. and Stephan, A. (1996). Problems of Democratic Transition and Consolidation: Southern Europe, South America, and Post-Communist Europe. Baltimore, Johns Hopkins University Press.

Loek, H. (2007). Political Values in Russell J Dalton and HansDieter Klingemann edt. The Oxford Handbook of Political Behavior. New York, Oxford University.

Nepal Economic Forum (2020). Nefport: Docking Nepal's Economic Analysis. March: Issue 40. https://issuu.com/ nepaleconomicforum/docs/nefport_40-2020-web.

Nepal-WWL 2020 Country Dossier (2020). NEPAL: Country 
Dossier, 2019. December. https://www.opendoorsusa.org/ wp-content/uploads/2019/01/WWL-2020-Country-DossierNepal.pdf.

Oxfam and HAMI (2019). Fighting Inequality in Nepal. https:// cng-cdn.oxfam.org/nepal.oxfam.org/s3 fs-public/file_ attachments/Fighting\%20Inequality\%20in\%20Nepal.pdf.

Smith, B. C. (2009). $3^{\text {rd }}$ Ed. Understanding Third World Politics: Theories of Political Change and Development. U.K. Palgrave Macmillan.

Sodaro, M. J. (2001). Comparative Politics: A Global Introduction. New York, McGraw Hill.

Tony Blair Institute for Global Change (2018). The Populist Harm to Democracy: An Empirical Assessment https:// institute.global/insight/renewing-centre/populist-harmdemocracy.

The Trading Economics (2019/2020). Nepal Imports|2001-2019 Data|2020-2022 Forecast. https://tradingeconomics.com/ nepal/imports.

Transparency International (2018). The Corruption Perception Index Report 2018. https://www.transparency.org/cpi2018.

USAID (2019). Agricultural and Food Security. https://www. usaid.gov/nepal/agriculture-and-food-security. Retrieved on 20/1/8.

Welzel, C. (2002). Effective Democracy, Mass Culture, and the Quality of Elites: The Human Development Perspective. In International Journal of Comparative Sociology. VL- 43(3), 269-290 